\title{
Tincture Dosage Form
}

National Cancer Institute

\section{Source}

National Cancer Institute. Tincture Dosage Form. NCI Thesaurus. Code C43000.

A solution composed of an alcoholic extract or solution of nonvolatile active and/or inert ing redient(s). 